\title{
Effect of the addition of peach palm (Bactris gasipaes) peel flour on the color and sensory properties of cakes
}

\author{
Jader MARTÍNEZ-GIRÓN ${ }^{1}$, Ana María FIGUEROA-MOLANO ${ }^{1}$, Luis Eduardo ORDÓÑEZ-SANTOS ${ }^{1 *}$
}

\begin{abstract}
This study aimed to evaluate the color and sensorial characteristics of a cake made with different amounts of flour made with peach palm peel flour. The flour was added at different concentrations, 2.5, 5.0, 7.5, and 10\% (w/w), including a control (tartrazine). Physiochemical analyses were carried out on the cakes, including total carotenoids, CIE- $\mathrm{L}^{*} \mathrm{a}^{*} \mathrm{~b}^{\star}$ color coordinates, and sensorial attributes. The results demonstrated that the peach palm peel flour substitution increased the total carotenoid content of the cakes. The color test showed that high levels of peach palm peel flour resulted in a decrease in the values of lightness $\left(\mathrm{L}^{\star}\right)$ and hue angle $\left(\mathrm{h}^{\circ}\right)$, while the values of browning index $(\mathrm{BI})$ and color change $\left(\Delta \mathrm{E}^{*}\right)$ increased significantly. The qualification of the sensorial evaluation indicated that the quality attributes were acceptable in the cakes made with wheat flour and $7.5 \%$ peach palm peel flour. Therefore, it was concluded that flour obtained from peach palm peel is a by-product that can be used as a natural food dye alternative in bread products.
\end{abstract}

Keywords: by-product; carotenoids; sensorial; lightness; chromaticity; hue.

Practical Application: This paper presents the addition of peach palm peel flour as natural food dye alternative in cakes.

\section{Introduction}

Color is one of the more important quality attributes for the commercialization of food. Consistent with this importance, the industry uses coloring additives, artificial or natural, in order to intensify, compensate or add coloring to manufactured products for an attractive and agreeable look, making them similar in appearance to the natural product (Pasias et al., 2015; Santos et al., 2014).

Traditionally, artificial food dyes, such as erythrosine, ponceau and tartrazine, are used in the processed food industry despite the health risks (Santos et al., 2014). Studies have reported that the consumption of artificial food dyes develops allergies and increases the risk of cancer (McCann et al., 2007; Mpountoukas et al., 2010). As a result, in recent years, the demand for natural food dyes has increased. For example, in 2007, the sale of natural food dyes reached 465 million dollars and it is expected that sales in 2017 will reach 1.3 billion dollars (Natural Products Insider, 2015). In recent years, natural food dyes, such as carotenoids, $\beta$-carotene (E160aii), bixin (E160b), paprika extract (E160c), lycopene (E160d) and $\beta$-Apo-8' carotenal (E160e), have been broadly used in the food, cosmetic, and pharmaceutical industries because, in addition to their coloring effect, they can impart health benefits in some cases through antioxidants and provitamin A and, in general terms, are seen as less harmful than their artificial counterparts (Santos et al., 2014; Berman et al., 2015; Pasias et al., 2015; Galaffu et al., 2015).

Yuyama et al. (2003) reported that the peach palm (Bactris gasipaes) is one of the more complete tropical foods due to its nutritional value because it has high contents of protein, essential amino acids and unsaturated fatty acids. Notably, this fruit has high contents of $\beta$-carotene, vitamin $\mathrm{A}$, calcium, phosphorus and iron
(Rojas-Garbanzo et al., 2011). Peach palm fruits are traditionally cooked or turned into flour, preserves, marmalade, or fermented beverages (Graefe et al., 2013). When processed, $18 \%$ of the fruit becomes residue, mainly the peel and seeds, which are currently not valued and represent an environmental problem. Babbar et al. (2015) reported that an effective option for managing fruit residue is the recovery of phytochemicals/bioactive compounds from the fruit residue, which can be used in the food, cosmetic and pharmaceutical industries.

Various studies have reported on the use of residues from the epicarp and mesocarp of fruits and vegetative parts in baked products. Netto-Rangel et al. (2011) carried out a sensorial evaluation of cakes that had sweet potato flour added to them, Aziah et al. (2011) conducted nutritional and sensorial analyses of cakes made with mango peel flour, Garzón et al. (2011) developed a highly nutritious baked product made with flour obtained with green bananas with the peel. Azizi et al. (2012) used different amounts of peach palm mesocarp flour to make bread, Yildiz \& Dogan (2014) carried out physicochemical and sensorial analyses of cakes made with chestnut flour, Mora et al. (2014) conducted proximal and sensorial analyses of cookies made with potato flour, and López-Calvo et al. (2015) carried out a sensorial analysis of snacks made with peach palm mesocarp. However, the potential of peach palm peel has not been researched; specifically it's potential as a source of natural food dyes as an alternative to artificial dyes in baked products. This study aimed to evaluate the color and sensorial characteristics of cakes made with different amounts of peach palm peel flour. 


\section{Materials and methods}

\subsection{Peach palm peel flour (PPPF) preparation}

Cooked peach palm fruit (Bactris gasipaes) were acquired in the municipal market in Palmira (Colombia), and then the epicarp (peels) was removed and cut. Peels was oven-dried at $60{ }^{\circ} \mathrm{C}$ until the moisture level was constant $(11 \% \mathrm{w} / \mathrm{w})$. Dried peel was ground to a powdered form using an electrical grinder and passed through a $0.25 \mathrm{~mm}$ sieve, and refrigerated until its later use.

\subsection{Formulation of cakes with peach palm peel flour}

The standard cake or control was made according to the AACC, "Approved Methods of the American Association of Cereal Chemists", Method 10-90, (American Association of Cereal Chemists, 1995). The formulation for the preparation of cake was used the method of (Offia-Olua \& Ekwunife, 2015) with some modifications: $75 \mathrm{~g}$ of American wheat flour manufactured by Harinera del Valle S.A, Colombia were mixed with $1.5 \mathrm{~g}$ of baking powder (Fleischmann Colombia), $72 \mathrm{~g}$ of margarine (Masaplus Multipremium Fleischmann Colombia), $75 \mathrm{~g}$ of eggs (Poultry Industry Golden Eggs Colombia), $75 \mathrm{~g}$ of sugar (Incauca S.A.S, Colombia), $10 \mathrm{~g}$ of whole milk (Parmalat Colombia Ltda), and $0.03 \mathrm{~g}$ of tartrazine E102 brand Goldine Yellow 5 (Fleischmann Colombia). The other samples were obtained by replacing the conventional wheat flour with $2.5,5.0,7.5$ and $10 \%$ peach palm peel flour and not adding any artificial food dyes. All of the dry ingredients were placed in a mixing bowl. The sugar and margarine were mixed for $7 \mathrm{~min}$, until a stable cream was obtained. Afterwards, the other ingredients were mixed with a paddle whisk on the second speed setting for $7 \mathrm{~min}$. The greased rectangular pans were filled with $300 \mathrm{~g}$ of the mixture. The prepared mixtures were baked at $215 \pm 2{ }^{\circ} \mathrm{C}$ (Oven bakery, Essen) for $25 \mathrm{~min}$ with $90 \% \mathrm{HR}$ and an internal temperature of $94 \pm 2{ }^{\circ} \mathrm{C}$.

\subsection{Physicochemical analysis}

The $\mathrm{pH}$ measurement and dry matter was performed according to Association of Official Analytical Chemists (1995). Total carotenoids were extracted and quantified according Barrett \& Anthon (2001), Ordóñez-Santos et al. (2014). Concentration $(\mathrm{mg} / 100 \mathrm{~g})$ was calculated using the molar extinction coefficients: $13.9 \times 10^{4} \mathrm{M}^{-1} \mathrm{~cm}^{-1}$ for $\beta$-carotene in hexane at $453 \mathrm{~nm}$, according to (Fish et al., 2002; Nagal et al., 2012). A Minolta CR-400 (Tokyo, Japan) color colorimeter was used for this study. The instrument was standardized each time with a black and a white $(Y=89.5$; $\mathrm{x}=0.3176 ; \mathrm{y}=0.3347$ ) tile using illuminant $\mathrm{D} 65$, and a $2^{\circ}$ observer. The parameters $L^{\star}, a^{\star} y b^{\star}$ were determined by reflectance CIE$\mathrm{L}^{*} \mathrm{a}^{\star} \mathrm{b}^{\star}$ color coordinates. In addition, the Chroma $\left(\mathrm{C}^{*}\right)$, hue angle $\left(\mathrm{h}^{\circ}\right)$, browning index $(\mathrm{BI})$, color index $\left(\mathrm{IC}^{\star}\right)$ and total color change $\left(\Delta \mathrm{E}^{\star}\right)$, were calculated by the Equations 1-6:

$$
\begin{aligned}
& C^{*}=\left(a^{* 2}+b^{* 2}\right)^{1 / 2} \\
& h^{\circ}=\tan ^{-1}\left(b^{*} / a^{*}\right) \\
& B I=100 \times(X-0.31 / 0.17)
\end{aligned}
$$

$$
\begin{aligned}
& X=\left(a^{*}+1.75 L^{*}\right) /\left(5.645 L^{*}+a^{*}-3.012 b^{*}\right) \\
& I C^{*}=\left(a^{*} \times 1000\right) /\left(L^{*} \times b^{*}\right) \\
& \Delta E^{*}=\left(\Delta a^{*^{2}}+\Delta b^{*^{2}}+\Delta L^{* 2}\right)^{1 / 2}
\end{aligned}
$$

The rheological characteristics for both wheat flour and peach palm peel flour were measured on a farinograph (Brabender, Druisburg, Germany), following the protocol of the AACC "Approved Methods of the American Association of Cereal Chemists (1995), Method 54-21. From the farinograph curve obtained for each flour characteristics such as water absorption, development time of the dough, dough stability, tolerance index and breakup time of the dough-water they were determined.

\subsection{Sensory evaluation}

The sensory characteristics of cakes incorporated with PPPF were conducted to determine the acceptability of the product according to method described by Ocen \& Xu (2013) with a slight modification. An untrained panel of 80 members (males and females) selected from University community with aged between 18 and 50 years performed the sensory evaluation of cakes. The panelists were guided on how to carry out the tests and the cakes were prepared using Good Manufacturing Practices (GMP). People of University community with allergic history to tartrazine E102 or intolerance to gluten (coeliacs) were excluded from the sensory evaluation. The ethical issues of the sensory analysis were developed as decribed in Institute of Food Science and Technology (2015) Guidelines for Ethical and Professional Practices for the Sensory Analysis of Foods and the Informed Consent Form (ICF) approved by the Independent Ethics Committee/Institutional Review Board (IRB/IEC) described by (Jacobs, 2010).

Cakes were evaluated on the basis of acceptance of their texture, color, taste, odor, and overall acceptability on a nine-point hedonic scale. The values ranged from "like extremely" to "dislike extremely" corresponding to the highest and lowest scores of "9"and " 1 ", respectively. Immediately before sensory testing, the cakes were sliced into $30 \mathrm{~mm}$ thick slice.

\subsection{Statistical analyses}

The experimental design was a randomized blocks, the treatments were control, 2.5, 5.0, 7.5 and 10\% PPPF, with five replicates per treatment. Data was analyzed with a one-way ANOVA and treatments means were compared using Tukey's test $(\mathrm{p} \leq 0.05)$. All statistical calculations were performed using SPSS 18 for Windows.

\section{Results and discussion}

\subsection{Physicochemical analysis of peach palm peel flour}

The physicochemical properties of the peach palm peel flour are listed in (Table 1). The $\mathrm{pH}$ and the acidity of the flour presented values close to those reported by Rojas-Garbanzo et al. (2012) for peach palm, raw, cooked and in flour (Table 1). The dry mass value for peach palm mesocarp flour reported by Oliveira et al. 
(2006) $92.91 \%$ agrees with the values recorded in the present study. The total carotenoid content in the peach palm peel flour samples exceeded those reported by De Rosso \& Mercadante, (2007) for palm fruits from the Amazon $19.7 \mathrm{mg} / 100 \mathrm{~g}$ Jatunov et al. (2010) $5.8 \pm 0.1 \mathrm{mg} / 100 \mathrm{~g}$, and Quesada et al. (2011) $7.4 \pm 0.2 \mathrm{mg} / 100 \mathrm{~g}$, Rojas-Garbanzo et al. (2011) reported $23.77 \mathrm{mg} / 100 \mathrm{~g}$ for peach palm mesocarp flour. The low $\mathrm{L}^{*}$ and $\mathrm{C}^{*}$ values and the high $\mathrm{BI}$ and $\mathrm{h}^{\circ}$ values indicated the presence of a dark yellow color in the peach palm peel flour the color of the flour was mainly due to the high carotenoid content levels $59.31 \mathrm{mg} / 100 \mathrm{~g}$ of flour (Table 1) and the existence of pigments generated during the dehydration process in the sample. On the other hand, Rojas-Garbanzo et al. (2011) reported L* $69 \pm 3$ and $\mathrm{C}^{\star} 73 \pm 5$ values in peach palm mesocarp flour that exceeded those obtained in the present study, unlike the $\mathrm{h}^{\circ} 71 \pm 1$ value, which agreed with our results (Table 1).

The rheological characteristics of the peach palm peel flour (PPPF) and the wheat four (WF) are listed in (Figures 1 and 2), respectively. The results indicated that the wheat flour was a strong type because it presented a good correlation between the development time and the dough rupture time, unlike the PPPF, which was a weak flour as indicated by the high values obtained for the dough stability and rupture time. This indicated

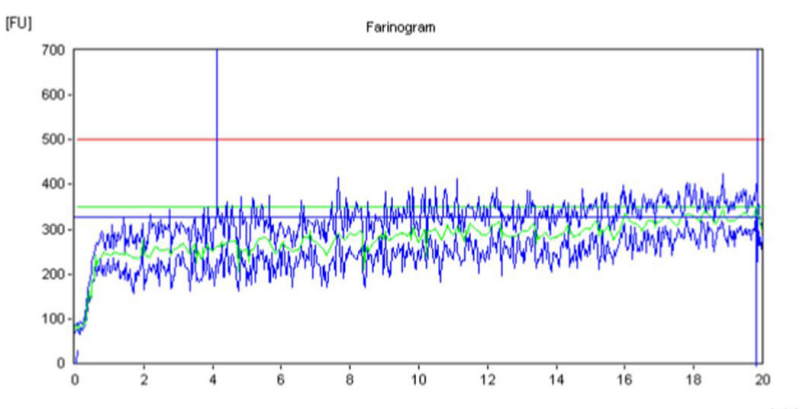

Figure 1. Farinograph of the peach palm peel flour.

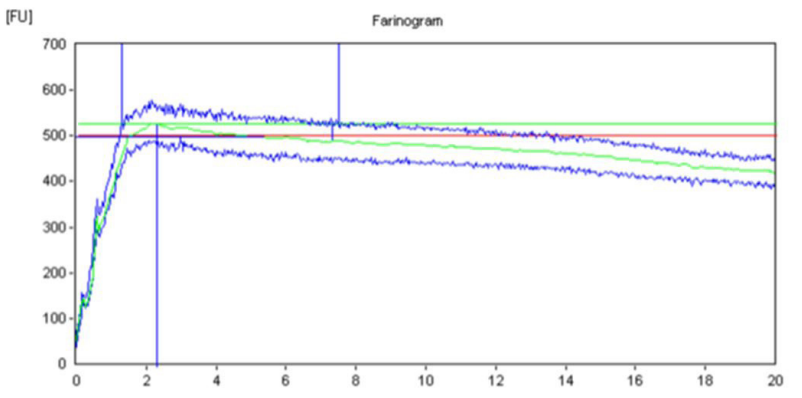

Figure 2. Farinograph of the wheat flour. that the partial substitution of WF with low concentrations of PPPF allows for the development of dough that is suitable for mixing with doughs used in baking. However, a substitution of WF with high concentrations of PPPF will generate an excessively porous and honeycombed crumb. The results in the graphs indicated that, for the PPPF, the water absorption was $60 \%$, the dough development time was $19.8 \mathrm{~min}$, the dough stability was $15.7 \mathrm{~min}$, the tolerance index was ( $10 \mathrm{FU})$ and the rupture time of the flour-water dough was $19.9 \mathrm{~min}$. Meanwhile, for the WF, the water absorption was $65.5 \%$, the dough development time was $2.3 \mathrm{~min}$, the dough stability was $6.2 \mathrm{~min}$, the tolerance index was $38 \mathrm{FU}$ and the rupture time of the flour-water dough was $5.4 \mathrm{~min}$.

The values obtained for the water absorption of the flours were similar to those reported by Osorio \& Galvis (2009) who reported a water absorption value of $63.8 \%$ in wheat flour and $64.4 \%$ in flour with $5 \%$ substitution with yuca flour, Visentín et al. (2009) reported values of $59.6 \%$ for water absorption in wheat flour and $60 \%$ for wheat flour with $6 \%$ substitution with soy flour, De la Horra et al. (2012) studied the rheological characteristics of different types of wheat flour and found $57.2 \%$ water absorption for a type 1 wheat flour along with a development time of $93 \mathrm{~min}$ and a stability of $12.2 \mathrm{~min}$ and, in a type 2 wheat flour, a $63.6 \%$ water absorption, a development time of $22.3 \mathrm{~min}$ and a stability of $14.7 \mathrm{~min}$, meaning the dough development time of the peach palm peel flour was lower than that of the type 2 wheat flour. Sánchez et al. (1998) reported that flours with a water absorption percentage close to 60 require minimum quantities of water or milk additions to form the dough, Paes et al. (2010) reported tolerance index values between 37 and $39 \mathrm{FU}$ and flour-water dough rupture time of $4.8 \mathrm{~min}$, which agree with the values obtained in the present study for the wheat flour. No previous studies were found for the rheological characteristics of peach palm peel flour. In similar studies Oliveira et al. (2006) studied the effect of adding $15 \%$ peach palm mesocarp flour to a wheat flour for making pasta, observing an increase in the absorption of water and in the dough development time, but a reduction in the stability and the tolerance index. Azizi et al. (2012) studied the addition of $5,10,15,20$ and $25 \%(\mathrm{w} / \mathrm{w})$ peach palm mesocarp flour to wheat flour for making bread. For the wheat flour, they obtained $63 \%$ water absorption, a development time of $2.5 \mathrm{~min}$ and a stability time of $2.5 \mathrm{~min}$. They reported that the addition of the peach palm mesocarp flour to the wheat flour resulted in an increase in the water absorption, an increase in the tolerance index, and a decrease in the dough stability time. The increases in the ability to absorb water seen in the wheat fortified with mesocarp flour were attributed to the fiber content and the carbohydrates found in peach palm fruits. The ability of the wheat to absorb water has a significant correlation with the development time due to the fact that the tolerance index increases with the addition of peach palm fruit flour.

Table 1. Physicochemical properties of the peach palm peel flour ${ }^{1}$.

\begin{tabular}{|c|c|c|c|c|c|c|c|}
\hline $\mathrm{pH}$ & Acidity $^{2}$ & $\begin{array}{c}\text { Dry } \\
\text { mass (\%) }\end{array}$ & $\begin{array}{c}\text { Total } \\
\text { Carotenoids }{ }^{3}\end{array}$ & $\mathrm{~L}^{*}$ & $\mathrm{C}^{*}$ & $\mathrm{~h}^{\circ}$ & BI \\
\hline $5.20 \pm 0.19$ & $0.17 \pm 0.05$ & $93.15 \pm 0.30$ & $59.31 \pm 1.61$ & $28.16 \pm 0.55$ & $14.20 \pm 0.72$ & $70.93 \pm 0.43$ & $75.10 \pm 3.17$ \\
\hline
\end{tabular}

${ }^{1}$ Mean values \pm SD $(n=5) ;{ }^{2}$ Expressed as the equivalent of citric acid per $100 \mathrm{~g}$ dry weight; ${ }^{3} \mathrm{mg} \beta$-Carotene/100g of sample; ${ }^{*}$ Reflectance CIE- $\mathrm{L}^{*} \mathrm{a}^{\star} \mathrm{b}^{\star}$ color coordinates. 


\subsection{Physicochemical analysis of cakes}

(Table 2) lists the physicochemical properties of the formulations evaluated in this study $(2.5,5.0,7.5$ and $10 \%$ PPPF), including the control (tartrazine). Statistically, there were significant differences $(\mathrm{p}<0.001)$ in the three evaluated response variables (Table 2).

The $\mathrm{pH}$ presented a slight decrease as the percentage of added PPPF increased, while the dry mass and the total carotenoid content significantly increased as compared to the control (Table 2). Azizi et al. (2012) also found an increase in the concentration of total carotenoids as the peach palm mesocarp flour substitution percentage increased in wheat flour for making bread. On the other hand, the comparison of the total carotenoid concentration in the PPPF and the cakes reflected a significant reduction in the concentration of carotenoid pigments (Tables 1 and 2). This loss could be associated with the mixing, whisking, and cooking (baking) processes of the cakes. Similarly Hidalgo et al. (2010) reported reductions in the carotenoid content when making bread and cookies.

(Table 3) shows the superficial color attributes evaluated in the crust and in the crumb for the cakes of this study. In all cases, in both the crust and the crumb, adding the flour significantly affected $(\mathrm{p}<0.001)$ the color variables of the cakes: the $\mathrm{L}^{\star}, \mathrm{b}^{\star}, \mathrm{C}^{\star}, \mathrm{h}^{\circ}$,

Table 2. Physicochemical properties of the cakes with different contents of peach palm peel flour.

\begin{tabular}{lccc}
\hline \multicolumn{1}{c}{ Formulation } & $\mathrm{pH}$ & Dry mass $(\%)$ & Carotenoids $^{1}$ \\
\hline Tartrazine & $5.9 \pm 0.2^{\mathrm{a}}$ & $77.4 \pm 0.7^{\mathrm{a}}$ & $0.07 \pm 0.009^{\mathrm{e}}$ \\
$2.5 \%$ PPPF & $5.7 \pm 0.1^{\mathrm{b}}$ & $78.6 \pm 0.3^{\mathrm{c}}$ & $2.1 \pm 0.2^{\mathrm{d}}$ \\
$5 \% \mathrm{PPPF}$ & $5.3 \pm 0.1^{\mathrm{c}}$ & $79.8 \pm 0.1^{\mathrm{b}}$ & $3.8 \pm 0.2^{\mathrm{c}}$ \\
$7.5 \%$ PPPF & $5.2 \pm 0.1^{\mathrm{cd}}$ & $80.4 \pm 0.3^{\mathrm{b}}$ & $5.1 \pm 0.3^{\mathrm{b}}$ \\
$10 \%$ PPPF & $5.1 \pm 0.1^{\mathrm{d}}$ & $81.8 \pm 0.4^{\mathrm{a}}$ & $7.1 \pm 0.3^{\mathrm{a}}$ \\
ANOVA & $(* * *)$ & $(* * *)$ & $(* * *)$ \\
\hline
\end{tabular}

$\left({ }^{* * *}\right) \mathrm{p}<0.001 ;{ }^{1} \mathrm{mg} \beta$-Carotene/100g of sample. Different letters in a column indicate a significant difference $(\mathrm{p}<0.001)$ between each formulation. and BI color parameters were significantly reduced and, on the other hand, the $\mathrm{a}^{\star}, \mathrm{IC}^{\star}$ and $\Delta \mathrm{E}^{\star}$ color parameters increased as the percentage of peach palm peel flour increased (Table 3 ). The samples with tartrazine presented the statistically highest values of $\mathrm{L}^{\star}, \mathrm{b}^{\star}, \mathrm{C}^{\star}, \mathrm{h}^{\circ}$, and $\mathrm{BI}$, while the cakes with this artificial food dye had the lowest values for $\mathrm{a}^{*}$ and $\mathrm{IC}^{*}$ (Table 3 ).

The increase in the color intensity as the percentage of added PPPF increased in the cakes was clearly the result of the increase in the dry material and the carotenoid concentration contributed by the PPPF (Figure 3 ).

Another factor that influenced these color changes in both the crust and crumb of the cakes was the non-enzymatic browning reactions (Maillard reaction and caramelization), which are influenced by the distribution of water and the reaction between reducing sugars and amino acids (Siddiq et al., 2009).

\subsection{Sensory analysis of cakes}

The effect of incorporating PPPF on the sensorial properties and the general acceptability of each of the formulations can be seen in (Table 4). It was determined with the sensorial analysis

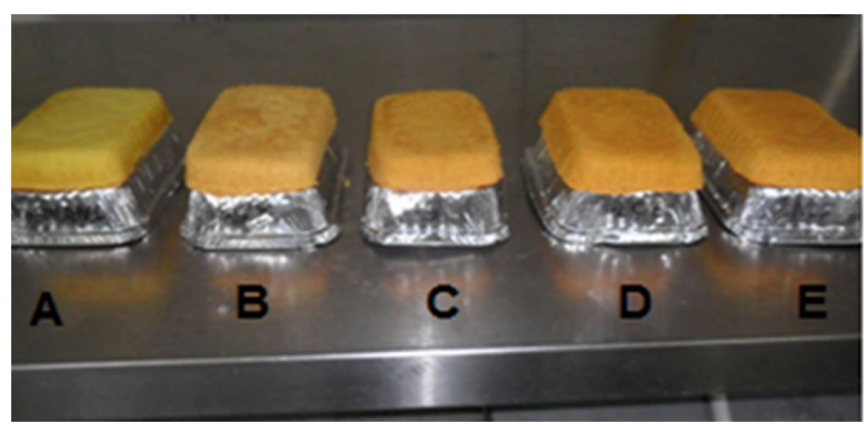

Figure 3. Evaluated cake colors. Tartrazine (A); 2.5\% PPPF (B); 5\% PPPF (C); 7.5\% PPPF (D); and 10\% PPPF (E). Source: authors.

Table 3. Crust and crumb color of the cakes with different contents of peach palm peel flour.

\begin{tabular}{|c|c|c|c|c|c|c|c|c|}
\hline \multicolumn{9}{|c|}{ Crust Color } \\
\hline Formulation & $\mathrm{L}^{*}$ & $a^{*}$ & $\mathrm{~b}^{*}$ & $\mathrm{C}^{*}$ & $\mathrm{~h}^{\circ}$ & BI & $\mathrm{IC}^{*}$ & $\Delta \mathrm{E}^{*}$ \\
\hline Tartrazine & $60.9 \pm 0.7^{\mathrm{a}}$ & $8.5 \pm 0.3^{c}$ & $42.2 \pm 0.4^{\mathrm{a}}$ & $43.0 \pm 0.4^{\mathrm{a}}$ & $78.6 \pm 0.3^{\mathrm{a}}$ & $118.1 \pm 2.6^{\mathrm{a}}$ & $3.3 \pm 0.1^{\mathrm{e}}$ & E.C \\
\hline $2.5 \% \mathrm{PPPF}$ & $52.9 \pm 0.6^{\mathrm{b}}$ & $16.7 \pm 0.3^{\mathrm{b}}$ & $32.2 \pm 0.4^{\mathrm{b}}$ & $36.3 \pm 0.4^{\mathrm{b}}$ & $62.5 \pm 0.5^{\mathrm{b}}$ & $111.9 \pm 2.6^{\mathrm{b}}$ & $9.8 \pm 0.2^{\mathrm{d}}$ & $15.2 \pm 0.3^{\mathrm{d}}$ \\
\hline $5 \%$ PPPF & $49.2 \pm 0.3^{c}$ & $17.1 \pm 0.3^{\mathrm{b}}$ & $29.3 \pm 0.5^{c}$ & $33.9 \pm 0.5^{c}$ & $59.7 \pm 0.5^{c}$ & $111.4 \pm 1.8^{\mathrm{b}}$ & $11.8 \pm 0.3^{c}$ & $19.4 \pm 0.4^{c}$ \\
\hline 7.5\% PPPF & $47.0 \pm 0.3^{\mathrm{d}}$ & $17.0 \pm 0.3^{\mathrm{b}}$ & $22.1 \pm 0.4^{\mathrm{d}}$ & $27.8 \pm 0.3^{\mathrm{d}}$ & $52.4 \pm 0.8^{\mathrm{d}}$ & $88.1 \pm 0.9^{c}$ & $16.4 \pm 0.6^{\mathrm{b}}$ & $25.9 \pm 0.5^{\mathrm{b}}$ \\
\hline $10 \% \mathrm{PPPF}$ & $44.1 \pm 0.2^{\mathrm{e}}$ & $17.5 \pm 0.3^{\mathrm{a}}$ & $20.1 \pm 0.2^{\mathrm{e}}$ & $26.7 \pm 0.3^{e}$ & $49.0 \pm 0.5^{\mathrm{e}}$ & $88.2 \pm 1.1^{\mathrm{c}}$ & $19.6997^{a}$ & $29.1 \pm 0.5^{\mathrm{a}}$ \\
\hline ANOVA & $(* * *)$ & $(* * *)$ & $(* * *)$ & $(* * *)$ & $(* * *)$ & $(* * *)$ & $(* * *)$ & $(* * *)$ \\
\hline \multicolumn{9}{|c|}{ Crumb Color } \\
\hline Formulation & $\mathrm{L}^{*}$ & $a^{*}$ & $b^{*}$ & $\mathrm{C}^{*}$ & $\mathrm{~h}^{\circ}$ & $\mathrm{BI}$ & $\mathrm{IC}^{*}$ & $\Delta \mathrm{E}^{*}$ \\
\hline Tartrazine & $63.1 \pm 0.3^{\mathrm{a}}$ & $1.9 \pm 0.1^{\mathrm{e}}$ & $49.9 \pm 0.6^{\mathrm{a}}$ & $49.9 \pm 0.6^{\mathrm{a}}$ & $87.7 \pm 0.1^{\mathrm{a}}$ & $136.1 \pm 2.8^{\mathrm{a}}$ & $0.6 \pm 0.04^{\mathrm{e}}$ & E.C \\
\hline $2.5 \% \mathrm{PPPF}$ & $60.3 \pm 0.4^{\mathrm{b}}$ & $5.4 \pm 0.1^{\mathrm{d}}$ & $42.5 \pm 0.5^{\mathrm{b}}$ & $42.9 \pm 0.5^{\mathrm{b}}$ & $82.7 \pm 0.1^{\mathrm{b}}$ & $117.4 \pm 2.5^{\mathrm{b}}$ & $2.1 \pm 0.04^{\mathrm{d}}$ & $8.7 \pm 0.5^{\mathrm{c}}$ \\
\hline $5 \% \mathrm{PPPF}$ & $55.9 \pm 0.4^{c}$ & $9.4 \pm 0.2^{c}$ & $42.3 \pm 0.5^{\mathrm{b}}$ & $43.3 \pm 0.5^{\mathrm{b}}$ & $77.5 \pm 0.3^{c}$ & $136.6 \pm 3.1^{c}$ & $3.9 \pm 0.1^{\mathrm{c}}$ & $12.8 \pm 0.4^{\mathrm{c}}$ \\
\hline 7.5\% PPPF & $57.2 \pm 0.3^{\mathrm{d}}$ & $10.4 \pm 0.2^{\mathrm{b}}$ & $35.4 \pm 0.3^{c}$ & $36.9 \pm 0.3^{c}$ & $73.6 \pm 0.2^{\mathrm{d}}$ & $104.4 \pm 1.7^{\mathrm{d}}$ & $5.1 \pm 0.1^{\mathrm{b}}$ & $17.8 \pm 0.3^{b}$ \\
\hline $10 \% \mathrm{PPPF}$ & $55.1 \pm 0.4^{\mathrm{e}}$ & $12.2 \pm 0.2^{\mathrm{a}}$ & $35.1 \pm 0.3^{c}$ & $37.2 \pm 0.3^{\mathrm{d}}$ & $70.8 \pm 0.4^{\mathrm{e}}$ & $111.6 \pm 1.3^{\mathrm{e}}$ & $6.3 \pm 0.1^{\mathrm{a}}$ & $19.7 \pm 0.4^{\mathrm{a}}$ \\
\hline ANOVA & $(* * *)$ & $(* * *)$ & $(* * *)$ & $(* * *)$ & $(* * *)$ & $(* * *)$ & $(* * *)$ & $(* * *)$ \\
\hline
\end{tabular}

$\left({ }^{* *}\right) \mathrm{p}<0.001$; EC (Control); ${ }^{*}$ Reflectance CIE- $\mathrm{L}^{*} \mathrm{a}^{*} \mathrm{~b}^{\star}$ color coordinates. Different letters in a column indicate a significant difference $(\mathrm{p}<0.001)$ between each formulation. 
Table 4. Sensorial evaluation of the cakes with different contents of peach palm peel flour

\begin{tabular}{lccccc}
\hline \multicolumn{1}{c}{ Formulation } & Texture & Color & Taste & Odor & Acceptance \\
\hline Tartrazine & $6.7 \pm 1.8^{\mathrm{b}}$ & $4.9 \pm 1.5^{\mathrm{d}}$ & $6.6 \pm 1.3^{\mathrm{b}}$ & $6.5 \pm 1.7^{\mathrm{b}}$ & $5.8 \pm 1.8^{\mathrm{d}}$ \\
$2.5 \%$ PPPF & $7.1 \pm 1.1^{\mathrm{b}}$ & $6.8 \pm 1.2^{\mathrm{c}}$ & $7.1 \pm 1.1^{\mathrm{a}}$ & $6.7 \pm 1.7^{\mathrm{b}}$ & $6.5 \pm 1.3^{\mathrm{c}}$ \\
$5 \%$ PPPF & $7.7 \pm 1.1^{\mathrm{a}}$ & $6.7 \pm 1.1^{\mathrm{c}}$ & $7.4 \pm 0.9^{\mathrm{a}}$ & $7.4 \pm 1.1^{\mathrm{a}}$ & $6.9 \pm 1.02^{\mathrm{b}}$ \\
$7.5 \%$ PPPF & $6.1 \pm 2.1^{\mathrm{c}}$ & $8.5 \pm 0.8^{\mathrm{a}}$ & $7.3 \pm 1.6^{\mathrm{a}}$ & $7.4 \pm 1.7^{\mathrm{a}}$ & $7.9 \pm 1.4^{\mathrm{a}}$ \\
$10 \%$ PPPF & $4.0 \pm 1.7^{\mathrm{d}}$ & $7.5 \pm 1.9^{\mathrm{b}}$ & $5.2 \pm 1.7^{\mathrm{c}}$ & $4.3 \pm 1.9^{\mathrm{c}}$ & $4.1 \pm 2.0^{\mathrm{e}}$ \\
ANOVA & $(* * *)$ & $(* * *)$ & $(* * *)$ & $(* * *)$ & $(* *)$ \\
\hline
\end{tabular}

$\left({ }^{* * *}\right) \mathrm{p}<0.001$; Different letters in a column indicate a significant difference $(\mathrm{p}<0.001)$ between each formulation.

that the increase in the percentage of PPPF statistically affected the texture, color, taste, odor, and general acceptance (Table 4).

The cakes with $2.5,5.0$ and $7.5 \%$ substitution with peach palm peel flour presented higher scores for the evaluated sensorial attributes; on the other hand, the formulations with tartrazine and 10\% PPPF had the lower scores for the evaluated sensorial parameters (Table 4). The highest quantification in terms of general acceptance was obtained with the $7.5 \%$ PPPF formulation (Figure 3).

Aziah et al. (2011) carried out a sensorial analysis of cakes made with additions of mango peel flour and found that $10 \%$ substitution was the best percentage. Garzón et al. (2011) developed a highly nutritious baked product using flour from green bananas with the peel and reported that $16 \%$ substitution was the best percentage, Azizi et al. (2012) used different amounts of peach palm mesocarp flour when making bread and found that $15 \%$ substitution had the best sensorial evaluation, Macías et al. (2013) found that 20\% substitution with carob flour presented good acceptance in cookies, Navas (2013) reported that 7\% substitution with soy flour presented good acceptance in arepas, Mora et al. (2014) carried out a sensorial analysis of cookies made with the addition of potato flour and found that $30 \%$ substitution was the maximum amount in order to obtain a product with acceptable quality.

\section{Conclusions}

Peach palm peel flour (PPPF) can be considered a natural food dye alternative for baked products in order to replace the artificial food dye tartrazine. The addition of PPPF increased the total carotenoid concentration in all of the analyzed cake formulations. The sensorial evaluations demonstrated that the cakes incorporated with PPPF, up to $7.5 \%$, had good acceptance. Therefore, peels generated after the consumption of cooked peach palm fruits can be transformed, by drying and milling them into flour, for use as a natural food dye option in baked products, thereby satisfying the preference of consumers for natural products over artificial products.

\section{Acknowledgements}

The National Research of Seed Program Creation and Innovation National University of Colombia 2013-2015, Colombia, supported this study.

\section{References}

American Association of Cereal Chemists. (1995). Approved methods of the American Association of Cereal Chemists. St. Paul: AACC International. Retrieved from http://methods.aaccnet.org/about.aspx

Association of Official Analytical Chemists. (1995). Official methods of Analysis of the Association off Official Analytical Chemists (16th ed.). Rockville: AOAC. Retrieved from http://www.aoac.org/ imis15_prod/AOAC/Publications/Official_Methods_of_Analysis/ AOAC_Member/Pubs/OMA/AOAC_Official_Methods_of_Analysis. aspx?hkey=5142c478-ab50-4856-8939-a7a491756f48

Aziah, A. A. N., Lee Min, W., \& Bhat, R. (2011). Nutritional and sensory quality evaluation of sponge cake prepared by incorporation of high dietary fiber containing mango (Mangifera indica var. Chokanan) pulp and peel flours. International Journal of Food Sciences and Nutrition, 62(6), 559-567. PMid:21534889. http://dx.doi.org/10.3 109/09637486.2011.562883.

Azizi, M. H., Andrade, J. S., Lemos, J. S., Souza, S. J., De Souza, R. S., \& Hadian, Z. (2012). Quality of wheat bread incorporated with different levels of peach palm flour (Bactris gasipaes Kunth). Journal of Tropical Agriculture and Food Science, 40(1), 13-22.

Babbar, N., Oberoi, H. S., \& Sandhu, S. K. (2015). Therapeutic and nutraceutical potential of bioactive compounds extracted from fruit residue. Critical Reviews in Food Science and Nutrition, 55(3), 319-337. PMid:24915390. http://dx.doi.org/10.1080/10408398.2011.653734.

Barrett, D. M., \& Anthon, G. (2001). Lycopene content of Californiagrown tomato varieties. Acta Horticulturae, 542(542), 165-174. http://dx.doi.org/10.17660/ActaHortic.2001.542.20.

Berman, J., Zorrilla-López, U., Farré, G., Zhu, C., Sandmann, G., Twyman, R. M., Capell, T., \& Christou, P. (2015). Nutritionally important carotenoids as consumer products. Phytochemistry Reviews, 14(5), 727-743. http://dx.doi.org/10.1007/s11101-014-9373-1.

De la Horra, A. E., Seghezzo, M. L., Molfese, E., Ribotta, P. D., \& León, A. E. (2012). Indicadores de calidad de las harinas de trigo: índice de calidad industrial y su relación con ensayos predictivos. Agriscientia, 29(2), 81-89.

De Rosso, V.V., \& Mercadante, A. Z. (2007). Identification and quantification of carotenoids, by HPLC-PDA-MS/MS, from Amazonian fruits. Journal of Agricultural and Food Chemistry, 55(13), 5062-5072. PMid:17530774. http://dx.doi.org/10.1021/jf0705421.

Fish, W. W., Perkins-Veazie, P., \& Collins, J. K. (2002). A quantitative assay for lycopene that utilizes reduced volumes of organic solvents. Journal of Food Composition and Analysis, 15(3), 309-317. http:// dx.doi.org/10.1006/jfca.2002.1069.

Galaffu, N., Bortlik, K., \& Michel, M. (2015). An industry perspective on natural food colour stability. Colour additives for foods and beverages, 1, 91-130. http://dx.doi.org/10.1016/B978-1-78242-011-8.00005-2.

Garzón, M. A. G., Acosta, L. M. V., Cardona, L. J. M., Hurtado, M. A. A., Rodriguez, A. C. D., Taborda, N. C., Gutiérrez, L. A. R., \& Mejia, 
G. C. V. (2011). Desarrollo de un producto de panadería con alto valor nutricional a partir de la harina obtenida del banano verde con cáscara: una nueva opción para el aprovechamiento de residuos de la industria de exportación. Producción + Limpia, 6(1), 96-107.

Graefe, S., Dufour, D., Van Zonneveld, M., Rodriguez, F., \& Gonzalez, A. (2013). Peach palm (Bactris gasipaes) in tropical Latin America: implications for biodiversity conservation, natural resource management and human nutrition. Biodiversity and Conservation, 22(2), 269-300. http://dx.doi.org/10.1007/s10531-012-0402-3.

Hidalgo, A., Brandolini, A., \& Pompei, C. (2010). Carotenoids evolution during pasta, bread and water biscuit preparation from wheat flours. Food Chemistry, 121(3), 746-751. http://dx.doi. org/10.1016/j.foodchem.2010.01.034.

Institute of Food Science and Technology. (2015). Guidelines for ethical and professional practices for the sensory analysis of foods. London: IFST. Retrieved from http://www.ifst.org/knowledgecentre-other-knowledge/ifst-guidelines-ethical-and-professionalpractices-sensory

Jacobs, M. (2010). Institutional review boards and independent ethics committees. In M. J. McGraw, A. N. George \& S. P. Shearn (Eds.), Principles of good clinical practice. London: Pharmaceutical Press. Retrieved from http://www.pharmpress.com/files/docs/ principles_clinpract_sample.pdf

Jatunov, S., Quesada, S., Díaz, C., \& Murillo, E. (2010). Carotenoid composition and antioxidant activity of the raw and boiled fruit mesocarp of six varieties of Bactris gasipaes. Archivos Latinoamericanos de Nutricion, 60(1), 99-104. PMid:21090177.

López-Calvo, R., Pérez, A. M., Ivankovich, G. C., Calderón, V. S., \& Pineda-Castro, M. L. (2015). Evaluación de la aceptación por consumidores de un bocadillo de pejibaye (Bactris gasipaes) y estudio de su potencial como alimento funcional. Archivos Latinoamericanos de Nutricion, 65(1), 51-58. PMid:26320306.

Macías, S., Binaghi, M. J., Zuleta, A., Ronayne, D. F., Costa, K., \& Generoso, S. (2013). Development of cookies with partial substitution of wheat flour with mesquite (Prosopis alba) flour and oats for social plans. Revista Venezolana de Ciencia y Tecnología de Alimentos, 4, 170-188.

McCann, D., Barrett, A., Cooper, A., Crumpler, D., Dalen, L., Grimshaw, K., Kitchin, E., Lok, K., Porteous, L., Prince, E., Sonuga-Barke, E., Warner, J. O., \& Stevenson, J. (2007). Food additives and hyperactive behaviour in 3-year-old and 8/9-year-old children in the community: a randomised, double-blinded, placebo-controlled trial. Lancet, 370(9598), 1560-1567. PMid:17825405. http://dx.doi. org/10.1016/S0140-6736(07)61306-3.

Mora, O. O., Cardenas, A. F., \& Bucheli, M. A. (2014). Elaboración de galletas a base de harina de papa de la variedad parda pastusa (Solanum tuberosum). Acta Agronomica, 63(2), 101-109. http:// dx.doi.org/10.15446/acag.v63n2.39575.

Mpountoukas, P., Pantazaki, A., Kostareli, E., Christodoulou, P., Kareli, D., Poliliou, S., \& Lialiaris, T. (2010). Cytogenetic evaluation and DNA interaction studies of the food colorants amaranth, erythrosine and tartrazine. Food and Chemical Toxicology, 48(10), 2934-2944. PMid:20667460. http://dx.doi.org/10.1016/j.fct.2010.07.030.

Nagal, S., Kaur, C., Choudhary, H., Singh, J., Bhushan, S. B., \& Singh, K. N. (2012). Lycopene content, antioxidant capacity and colour attributes of selected watermelon (Citrullus lanatus (Thunb M.) cultivars grown in India. International Journal of Food Sciences and Nutrition, 63(8), 996-1000. PMid:22716946. http://dx.doi.or g/10.3109/09637486.2012.694848.
Natural Products Insider. (2015). The natural color palette. Retrieved from http://www.foodproductdesign.com/digital-issues/2015/05/ natural-colors.aspx

Navas, H. (2013). Quantification of polyphenols, total flavonoids and isoflavones in arepas made with the partial addition of defatted soybean flour (Glycine max). Revista Venezolana de Ciencia y Tecnología de Alimentos, 4, 237-249.

Netto-Rangel, C., Silva, E. M. M., Salvador, L., Figueiredo, R., Watanabe, E., Silva, J. B. C., Carvalho, J. L., \& Regini, N. M. (2011). Sensory evaluation of cakes prepared with orange-fleshed sweet potato flour (Ipomoea batatas L.). Perspectivas en Nutrición Humana, 13, 203-211.

Ocen, D., \& Xu, X. (2013). Effect of citrus orange (Citrus sinensis) by-product dietary fiber preparations on the quality characteristics of frozen dough bread. American Journal of Food Technology, 8(1), 43-53. http://dx.doi.org/10.3923/ajft.2013.43.53.

Offia-Olua, B. I., \& Ekwunife, O. A. (2015). Production and evaluation of the physico-chemical and sensory qualities of mixed fruit leather and cakes produced from apple (Musa pumila), banana (Musa sapientum), pineapple (Ananas comosus). Nigerian Food Journal, 33(1), 22-28. http://dx.doi.org/10.1016/j.nifoj.2015.04.004.

Oliveira, M. K., Martinez-Flores, H. E., De Andrade, J. S., GarnicaRomo, M. G., \& Chang, Y. K. (2006). Use of pejibaye flour (Bactris gasipaes Kunth) in the production of food pastas. International Journal of Food Science \& Technology, 41(8), 933-937. http://dx.doi. $\operatorname{org} / 10.1111 / \mathrm{j} .1365-2621.2005 .01145 . x$.

Ordóñez-Santos, L. E., Martínez-Álvarez, G. M., \& Vázquez-Riascos, A. M. (2014). Effect of processing on the physicochemical and sensory properties of Mammee Apple (Mammea americana L.) Fruit. Agrociencia, 48, 377-385.

Osorio, S. H., \& Galvis, J. A. (2009). Influencia de la variedad de yuca y nivel de sustitución de harinas compuestas sobre el comportamiento reológico en panificación. Ingeniería e Investigación, 29, 39-46.

Paes, J. L., Faroni, L. R., Dos Santos, J. E., \& Urruchi, W. I. (2010). Calidad tecnológica de la harina de trigo obtenida a partir de cereales ozonizados. Ciencias Biológicas, 41, 1-11.

Pasias, I. N., Asimakopoulos, A. G., \& Thomaidis, N. S. (2015). Food colours for bakery products, snack foods, dry soup mixes, and seasonings. Colour Additives for Foods and Beverages, 211-226. http://dx.doi.org/10.1016/B978-1-78242-011-8.00008-8.

Quesada, S., Azofeifa, G., Jatunov, S., Jiménez, G., Navarro, L., \& Gómez, G. (2011). Carotenoids composition, antioxidant activity and glycemic index of two varieties of Bactris gasipaes. Emirates Journal of Food and Agriculture, 23, 482-489.

Rojas-Garbanzo, C., Pérez, A. M., Bustos-Carmona, J., \& Vaillant, F. (2011). Identification and quantification of carotenoids by HPLCDAD during the process of peach palm (Bactris gasipaes HBK) flour. Food Research International, 44(7), 2377-2384. http://dx.doi. org/10.1016/j.foodres.2011.02.045.

Rojas-Garbanzo, C., Pérez, A. M., Pineda-Castro, M. L., \& Vaillant, F. (2012). Major physicochemical and antioxidant changes during peach-palm (Bactris gasipaes HBK) flour processing. Fruits, 67(6), 415-427. http://dx.doi.org/10.1051/fruits/2012035.

Sánchez, D. H., Osella, C. A., \& Torre, M. A. (1998). Mejoramiento de la calidad nutricional de pan tipo francés. Archivos Latinoamericanos de Nutricion, 48(4), 349-353. PMid:10347701.

Santos, L. F., Dias, V. M., Pilla, V., Andrade, A. A., Alves, L. P., Munin, E., Monteiro, V. S., \& Zilio, S. C. (2014). Spectroscopic and photothermal characterization of annatto: Applications in 
functional foods. Dyes and Pigments, 110, 72-79. http://dx.doi. org/10.1016/j.dyepig.2014.05.018.

Siddiq, M., Nasir, M., Ravi, R., Butt, M. S., Dolan, K. D., \& Harte, J. B. (2009). Effect of defatted maize germ flour addition on the physical and sensory quality of wheat bread. LWT - Food Science and Technology (Campinas.), 42, 464-470. http://dx.doi.org/10.1016/j. lwt.2008.09.005.

Visentín, A. N., Drago, S. R., Osella, C. A., De la Torre, M. A., Sánchez, H. D., \& González, R. J. (2009). Efecto de la adición de harina de soja y concentrado proteico de suero de queso sobre la calidad del pan y la dializabilidad de minerales. Archivos Latinoamericanos de Nutricion, 59(3), 325-331. PMid:19886519.
Yildiz, Ö., \& Dogan, I. S. (2014). Optimization of gluten-free cake prepared from chestnut flour and transglutaminase: Response surface methodology approach. International Journal of Food Engineering, 10(4), 737-746. http://dx.doi.org/10.1515/ijfe-2014-0024.

Yuyama, L. K., Aguiar, J. P., Yuyama, K., Clement, C. R., Macedo, S. H., Fávaro, D. I., Afonso, C., Vasconcellos, M. B., Pimentel, S. A., Badolato, E. S., \& Vannucchi, H. (2003). Chemical composition of the fruit mesocarp of three peach palm (Bactris gasipaes) populations grown in Central Amazonia. Brazil. International Journal of Food Sciences and Nutrition, 54(1), 49-56. http://dx.doi.org/10.1080/09 6374803/000061994. PMid:12701237. 